IRA-International Journal of Technology \& Engineering ISSN 2455-4480; Vol.06, Issue 02 (2017)

Pg. no. 24-28

Institute of Research Advances http://research-advances.org/index.php/IRAJTE

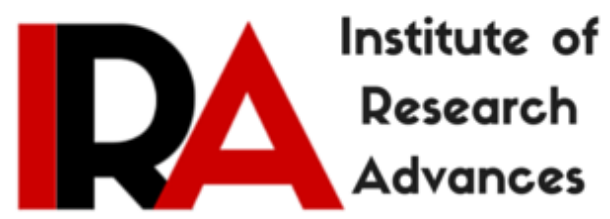

\title{
Chemical Profile and Extraction Technique of Oil of Mentha Arvensis
}

\author{
M.A.Nadeem ${ }^{1}$, B.K.Saxena ${ }^{2}$, N.Akbar ${ }^{3}$ \\ ${ }^{1}$ Institute of Technology and Management, Gwalior, India. \\ ${ }^{2}$ DAV-PG Collage, Kanpur, India. \\ ${ }^{3}$ Fragrance \& Flavour Development Centre, Kannauj, India.
}

Type of Reviewed: Peer Reviewed.

DOI: http://dx.doi.org/10.21013/jte.v6.n2.p2

How to cite this paper:

Nadeem, M., Saxena, B., \& Akbar, N. (2017). Chemical Profile and Extraction Technique of Oil of Mentha Arvensis. IRA-International Journal of Technology \& Engineering (ISSN 2455-4480), 6(2), 24-28. doi:http://dx.doi.org/10.21013/jte.v6.n2.p2

(C) Institute of Research Advances

(c) B EY-NC

This work is licensed under a Creative Commons Attribution-Non Commercial 4.0 International License subject to proper citation to the publication source of the work.

Disclaimer: The scholarly papers as reviewed and published by the Institute of Research Advances (IRA) are the views and opinions of their respective authors and are not the views or opinions of the IRA. The IRA disclaims of any harm or loss caused due to the published content to any party. 


\section{ABSTRACT}

Menthol mint oil is distilled by water steam distillation from leaves of Mentha arvensis and is the most importance source of L-menthol. It contains L-menthol $68.3 \%$, menthone $8.2 \%$, isomenthone $4.4 \%$, menthyl acetate $4.3 \%$, mixture of isomers of menthol 4.5\%, cis-3- hexanal $0.2-\%$ and limonene $1.2 \%$, However percentage of components depends on the genetic and ecological conditions. Major component L-Menthol is isolated by freezing at low temperature with the recovery of around $65 \%$ in form of menthol flakes and the remaining material is known as DMO or dementholised oil (30\%). During the process 1\% loss is generally found. All the components are being used in Flavours, Pharmaceuticals, Tobacco and other cosmetic Industries.

Keywords: Crystallization; Dementholised Oil; Essential oil; Mentha arvensis; Menthol bold crystals; Menthol flakes; Odour evaluation; Terpenes.

\section{Introduction}

Mint oil comes under the category of essential oils also known as Mentha. It's by product is dementholised oil (DMO) and it a source of terpenes, menthyl acetate and liquid menthol. Mentha is basically divided into various categories like Mentha arvensis, Mentha piperita, Mentha citrate, Mentha spicata, Mentha gracilis, Mentha Longifolia and various others, thanks to agriculture science. Menthol mint is the backbone of livelihood for thousands of farmers across the northern plains of India. At present, India is global leader in mint oil production covering nearly $90 \%$ of total world production out of which around 85\% is spread out in Uttar Pradesh such as Barabanki, Sambhal, Moradabad, Budaun, Rampur and Bareilly. The rest 15\% is in Punjab, Madhya Pradesh and Bihar. This was all done through a systematic but economically driven total value chain right from development of variety to extension, survey of status of mint and there after introduction of multi commodity exchange for forward trading. Lot of MSMEs are involved in the distillation and trade related to menthol mint in India.

In India it was introduced in 1954 by Regional Research Laboratory Jammu (now Indian Institute of Integrative Medicine). In 1964 it all started in tarai region of Uttar Pradesh by M/s Hindustan Richardson Ltd., Mumbai. Subsequently it started increasing and reached to a level of $250 \mathrm{M}$ tonnes in 1976. In 1980 the existing clone of Menthol mint started deteriorating, then variety development programme was taken up by Central Institute of Medicinal \& Aromatic Plants (CIMAP), Lucknow. As a result CIMAP/MAS-1 was developed in 1983 and later Shivalik (1990), Gomti (1995), Himalaya (1996) Kosi (1998) and recently released CIM- Kranti were also developed. In spite of development of many improved verities like Kosi and recently released CIM- Kranti, most of the farmers are cultivating old varieties like Shivalik and Himalaya developed during 1990 and 1996 due to lack of awareness.

There is need to create awareness among farmers to adopt cultivation of recently developed high quality varieties for high yield in terms of quality and quantity. In this paper we were emphasized on routine industrially accepted and viable technology used for the extraction of essential oil of menthol mint and production of crystals of different grade and quality as flakes and bold crystals. The physico chemical and instrumental testing is also mentioned hereby compare with the International and National standards.

\section{Materials and Methods}

The mint oil is mainly produced in the region of Uttar Pradesh, Bihar, Madhya Pradesh \& Himalayan region, which is extracted by the Mentha leaves by the help of water steam distillation method and the yield obtain is about 0.3 to $0.5 \%$. The major demand is the Menthol crystals which are mainly 
used by tobacco, pan masala, and pharmaceutical industries. These crystals are prepared by the two methods.

\section{Convectional Method}

This method practices into the deep freezer which is at $-45^{\circ} \mathrm{C}$ about 48 hours. Further the freeze oil is transferred into basket centrifuge in which the menthol crystals are separated in the form of flakes which is also known as DMO (dementholised oil).

\section{Improved Method}

This process is basically used for the separation of undesirable products like monoterpenes \& menthone. The oil which is remaining is further rectified and known as terpeneless oil.

The Mentha arvensis is tested for its physical and chemical properties like viz optical rotation, refractive index, specific gravity, solubility, congealing points and flash point and compared with National standard as shown in Table-III. Some important tests as alkaline test, paper test, water test and solid sedimentation test were also performed to check the quality as well as any adulteration or foreign materials involvement. Further, the oil of mint was also analyzed for determination of valuable and major components using Hewlett Packard 5890 series II gas chromatograph equipped with flame ionization detector (FID) and Carbowax $20 \mathrm{~mm}$ polar fused silica capillary column (30m x $0.32 \mathrm{~mm}$.). The injector and detector temperature were maintained $210^{\circ} \mathrm{C}$ and $220^{\circ} \mathrm{C}$, respectively. Nitrogen was used as carrier gas with the flow rate of $1.5 \mathrm{ml} / \mathrm{min}$. Sample volume of $0.1 \mu \mathrm{L}$ with the split less mode of injection was used (split ratio 60:1). Initial Oven temperature was programmed at $130^{\circ} \mathrm{C}$, held for 5 minutes, then raised to $185^{\circ} \mathrm{C}$ at the rate of $2^{\circ} \mathrm{C} / \mathrm{min}$ and held for 5 minutes, finally raised to $230^{\circ} \mathrm{C}$ at the rate of $8^{\circ} \mathrm{C} / \mathrm{min}$ and was held for 20 minutes. Temperature of the Injector and detector was maintained at $250^{\circ} \mathrm{C}$ and $270^{\circ} \mathrm{C}$ respectively. The components were identified by comparing the retention time with those reported in the literatures. Percentage of individual component was calculated based on the GC peak areas. The oil was also compared with International Standard as shown in Table-IV .

During the crystallization of menthol mint oil, the menthol flakes and menthol bold crystals were also tested for purity and odour evaluation as shown in table-II.

\section{Results and Discussion}

Table I shows the Mentha arvensis oil parameters according to which the sample is tested. The researches shows that the menthol content of Uttar Pradesh and Himalayan is good that any other region. Where in the case of Himalayan oil, it is slightly superior in its appearance and the melting point. Based on chromatographic analysis of tested sample, major components as L-Menthol 68.3\%, menthone 8.2\%, Isomenthone $4.4 \%$, menthol isomers $4.5 \%$, menthyl acetate $4.3 \%$, limonene $1.2 \%$, cis-3-hexanol $0.2 \%$, mixture of various terpenes $7.7 \%$ and total menthol content $76.9 \%$ were found. The same sample was processed for production of menthol flakes by conventional method, the recovery of flakes was found $65 \%$ with process lose of $1 \%$. The dementholised oil was also produced as byproduct with recovery of $30 \%$. The high value of congealing point indicates the maximum purity of L- Menthol and it was found $99.0 \%$ by GLC analysis. In second improve method, the purity of menthol flakes was found $99.5 \%$ or above with no traces of monoterpenes in final product. It means terpeneless menthol flakes are superior in odour evaluation and widely used in flavour, Tobacco and pharmaceutical industries. 
Table-I Quality characteristics of Mentha Arvensis

\begin{tabular}{|c|l|l|}
\hline S.No. & Parameters & Values/ Results \\
\hline 1. & Optical Rotation & $-33.5^{\circ} \mathrm{C}$ \\
\hline 2. & Specific Gravity at $27^{\circ} \mathrm{C}$ & 0.8988 \\
\hline 3. & Solubility in $70 \%$ Ethyl alcohol at $27^{\circ} \mathrm{C}$ & Up to 3 volume \\
\hline 4. & Refractive Index at $27^{\circ} \mathrm{C}$ & 1.4590 \\
\hline 5. & Congealing Point & $21^{\circ} \mathrm{C}$ \\
\hline 6. & Alkaline Test & Transparent or negative \\
\hline 7. & Solid Sedimentation test & $0.02 \%$ \\
\hline 8. & Paper test & Negative or pure \\
\hline 9. & Water test & $0.63 \%$ \\
\hline 10. & Flash Point & $75^{\circ} \mathrm{C}$ \\
\hline 11. & L-Menthol & $68.3 \%$ \\
\hline 12. & Total Menthol Content(TMC) & $76.9 \%$ \\
\hline 13. & Menthone & $8.2 \%$ \\
\hline 13. & Isomenthone & $4.4 \%$ \\
\hline 14. & Menthyl acetate & $4.3 \%$ \\
\hline 15. & Menthol isomers & $4.5 \%$ \\
\hline 16. & Limonene & $1.2 \%$ \\
\hline
\end{tabular}

Table -II Quality characteristics of flakes

\begin{tabular}{|l|l|l|}
\hline S.No. & Parameters & Values \\
\hline 1. & Congealing point & $44^{\circ} \mathrm{C}$ \\
\hline 2. & Optical rotation & -52 \\
\hline 3. & L-Menthol & $99.5 \%$ \\
\hline
\end{tabular}

Table -III National standard (BIS) of oil of Mentha Arvensis

\begin{tabular}{|l|l|l|l|}
\hline $\begin{array}{c}\text { S. } \\
\text { No. }\end{array}$ & Characteristic & Requirement & Method of Test \\
\hline 1. & Colour and Appearance & $\begin{array}{l}\text { Colourless and pale yellow or greenish yellow } \\
\text { liquid }\end{array}$ & IS 326(Part 2) \\
\hline 2. & Odour & $\begin{array}{l}\text { Characteristic strong minty, herbal followed } \\
\text { by cooling sensation }\end{array}$ & IS 2284 \\
\hline 3. & Relative density at $27^{\circ} \mathrm{C}$ & 0.877 to 0.912 & IS 326(Part 3) \\
\hline 4. & Refractive index at $27^{\circ} \mathrm{C}$ & 1.4560 to 1.4640 & IS 326(Part 5) \\
\hline 5. & Optical rotation at $27^{\circ} \mathrm{C}$ & $-35^{\circ}$ to $-45^{\circ}$ & IS 326(Part 4) \\
\hline 6. & $\begin{array}{l}\text { Solubility in ethanol (volume } \\
\text { fraction } 70 \% \text { ) at } 27^{\circ} \mathrm{C}\end{array}$ & 2 to 4 volumes of ethanol & IS 326 (Part 6) \\
\hline 7. & $\begin{array}{l}\text { Esters as menthyl acetate } \\
\text { percent by mass, }\end{array}$ & 3 to 15 & IS 326(Part 8) \\
\hline 8. & $\begin{array}{l}\text { Free alcohol as 1-menthol } \\
\text { percent by mass, Min }\end{array}$ & 60 & IS 326(Part 9) \\
\hline 9. & $\begin{array}{l}\text { Total alcohol as l-menthol } \\
\text { percent by mass, Min }\end{array}$ & 65 & IS 326(Part 11) \\
\hline 10. & $\begin{array}{l}\text { Ketone as menthone percent } \\
\text { by mass ( using free } \\
\text { hydroxylamine method }\end{array}$ & 5 to 20 & \\
\hline
\end{tabular}


IRA-International Journal of Technology \& Engineering

Table -IV International standards (ISO) of oil of Mentha Arvensis

\begin{tabular}{|c|c|c|c|}
\hline $\begin{array}{l}\text { S. } \\
\text { No. }\end{array}$ & Characteristic & Requirement & $\begin{array}{l}\text { Method of } \\
\text { Test } \\
\end{array}$ \\
\hline 1 & Appearance & Clear, mobile liquid & \\
\hline 2 & Colour & Almost colourless to amber yellow & \\
\hline 3 & Odour & Characteristic of mint, menthol-like & \\
\hline 4 & Relative density at $20^{\circ} \mathrm{C}$ & 0.890 to 0.910 & ISO 279 \\
\hline 5 & Refractive index at $20^{\circ} \mathrm{C}$ & 1.4570 to 1.4650 & ISO 280 \\
\hline 6 & Optical rotation at $20^{\circ} \mathrm{C}$ & $-22^{\circ}$ to $-13^{\circ}$ & ISO 592 \\
\hline 7 & $\begin{array}{l}\text { Miscibility in ethanol } \\
\text { (volume fraction } 70 \% \text { ) at } 20 \\
{ }^{\circ} \mathrm{C}\end{array}$ & $\begin{array}{l}1 \text { volume of oil shall require a maximum of } 4 \\
\text { volumes of ethanol to obtain a clear solution. }\end{array}$ & ISO 875 \\
\hline 8 & Acid value & Maximum: 1 & ISO 1242 \\
\hline 9 & Ester value & \begin{tabular}{|l}
8 to 25 Corresponding to an ester content, expressed \\
as menthyl acetate, of $3 \%$ to $9 \%$ \\
\end{tabular} & ISO 709 \\
\hline 10 & $\begin{array}{l}\text { Menthol content by } \\
\text { determination of ester value } \\
\text { after acetylation }\end{array}$ & $40 \%$ to $60 \%$ (expressed as free menthol) & ISO 1241 \\
\hline 11 & Carbonyl value & $\begin{array}{l}91 \text { to } 146 \\
\text { Corresponding to a menthone content of } 25 \% \text { to } \\
40 \%\end{array}$ & ISO 1271 \\
\hline 12 & Flash point & $\begin{array}{l}\text { Mean value is }+75^{\circ} \mathrm{C} \text { (of partially dementholised } \\
\text { oil) }\end{array}$ & \\
\hline
\end{tabular}

\section{Conclusion}

It is clearly indicated from the analytical data that the impact of main components on the odour intensity of menthol mint oil is high. Based on chemical profile, percentage of major components is around $90 \%$. Total recovery of menthol flakes depends upon the percentage of L- Menthol content of the oil. The purity of menthol fakes is very near to $100 \%$ because it is process at low temperature around $45^{0} \mathrm{C}$.

\section{References}

1. KK.Aggarwal, AA.Naqvi, AP.Kahol (1986). Improved Process for the recovery of liquid menthol from dementholised oil ex Mentha arvensis by a packed column under high vacuum. PAFAI Journal, 8: 21 - 24.

2. S.Kumar, BR.Tyagi, JR.Bahl, SPS.Khannuja , AK.Varshnay, RS.Shukla, A.Sattar, D.Singh, A.Haseed , VP.Singh, P.Ram, S.Singh, SP.Singh, NK.Patra, M.Alam, M.Ram, KK.Aggarwal (1997) . Himachal a high menthol yielding hybrid clone of Mentha arvensis, Journal of Medicinal and Aromatic Plants Sciences, 19: $729-731$.

3. S. Kumar, AP. Kahol, DD. Patra, P.Ram, S.Singh, BR.Tyagi (1997). Menthol Mint cultivation in India, Bulletin No 004, CIMAP, Lucknow, India .

4. Anonymous (1999). International Standard Specification for oil of Mentha arvensis, no. ISO: 9776, International committee ISO/TC54, Essential oils, Case postale 56.CH-1211 Genève 20.Switzerland.

5. B.M.Lawrence (2004). Progress in essential oils, Perfum. Flavor, 29: 2004, 88.

6. K.husnu Can Baser (2010).Hand book of essential oils science, technology, and application, Edited by, Gerhard Buchbauer CRC Press, Taylor \& Francis group, LLC.

7. Gunkel W, Fraser LC, (2010). Hand Book of Essential Oils, Science \& Technology and Applications, Volume 1, CRC press publications, New Delhi, 156 - 162: 330 - 332. 